\title{
ECONOMICS OF THE 2009-2012 ORGANIC APPLE, STRAWBERRY, AND SOUR CHERRY PRODUCTION IN POLAND
}

\author{
Piotr Brzozowski and Krzysztof Zmarlicki \\ Research Institute of Horticulture \\ Konstytucji 3 Maja 1/3, 96-100 Skierniewice, POLAND \\ e-mail: Piotr.Brzozowski@inhort.pl; Krzysztof.Zmarlicki@inhort.pl
}

(Received September 12, 2012/Accepted November 26, 2012)

\section{A B S T R A C T}

Certified organic farm area in Poland increased 8.5 fold during the 2003-2010 time period to 518 thousand ha, which constituted $2.8 \%$ of the arable land. The production costs and profitability of the organic fruit production of apples, strawberries, and sour cherries were evaluated and compared to conventional production of those fruits. The research was based on data from thirty-two commercial fruit farms; twenty farms with conventional production, and twelve with organic production. The main problems associated with organic production were the costs of weed control and soil cultivation. The conventional production of apples turned out to be slightly more profitable than the organic production. The organic production of sour cherries was not profitable. In the case of strawberries, it was the opposite - the organic production gave a better financial outcome than the conventional one.

Key words: costs, organic apples, organic sour cherries, organic strawberries, profitability

\section{INTRODUCTION}

Organic farming became one of the fastest growing segments of Polish agriculture during the 2000s. Accordingly to the Polish Ministry of Agriculture and Rural Development, the area under certified organic practice increased 8.5 fold from 2003 to
2010 , to 518 thousand ha, which made up $2.8 \%$ of the total arable land. Aside from the environmental and health benefits, organic fruit production could also be profitable. Producers may receive additional governmental and institutional support (Brzozowski and Zmarlicki, 2010). The use of most synthetic chemical pesticides and 
fertilizers is strictly limited in organic farming. Mostly naturally derived products are in use as defined by organic certification programs and the standards set by the International Federation of Organic Agriculture Movements (IFOAM). This worldwide movement emerged in Europe where IFOAM was founded, in Versailles - France in 1972 (Weibel et al., 2004). The legal framework for organic agriculture and foodstuffs obtained organically was set by the Council Regulation (EEC) No 2092/91, in 1991.

The objective of this research was the evaluation of production costs and the profitability of apple, strawberry and sour cherry fruit production. A comparison with the conventional production of the above mentioned fruit was also made.

\section{MATERIAL AND METHODS}

The research was carried out during the 2009-2012 time period, on thirty-two commercial fruit farms. Twenty were apple producing farms, of which twelve used conventional production methods, and eight used organic production methods. Eleven were strawberry producing farms, of which six used conventional production methods and five, organic. Six farms produced sour cherries; four with conventional and two with organic production methods. Usually the data for each species were taken from each separate farm. But in two cases, the respective data for conventional production of sour cherries and apples were taken from the same farms. The same was also done for three cases of organic production. There were two cases where apples and sour cherries were grown on the same farms, and one case where apples and strawberries were grown on the same farms. As a result, in our research, the number of particular records is thirty- seven, but the number of participating farms is thirtytwo. The investigated farms were all located in the central part of Poland. Most organic producers converted existing conventional orchards, rather than planted new ones.

For both the organic and conventional systems, appropriate management practices were applied as required by the certification rules for organic farms.

The size of the studied apple orchards ranged from 0.5 ha to 3.5 ha for the organic system and from 0.5 ha to 7.0 ha for the conventional system. The planting density was from 250 to 1000 trees per hectare for the organic systems and from around 450 to 1660 trees per hectare for the conventional ones. The trees were from 8 to 36 years old. The size of the sour cherry orchards ranged from 0.4 ha to 1.0 ha for the organic system and from 0.5 ha to 2.0 ha for the conventional system. The density of planting was around 840 trees per hectare for both systems. The trees were from 5 to 12 years old. The sizes of the strawberry fields on the investigated farms were from 0.2 ha to 3.3 ha.

Because of a conspicuous technological and economical gap between conventional and organic farming, 
Economics of the 2009-2012 organic apple...

the conventional farms for our investigation were taken from the less successful half of our set of farms. All data necessary for the calculation of the costs and profitability were obtained from producers through the use of special questionnaires, and during additional interviews.

\section{RESULTS}

The average yields of organicallyproduced apples in the years 20092012 amounted to 13.0 tons per hectare, while in the conventional system, 25.7 tons per hectare. Average yearly yields were rather undifferentiated but across the investigated set of organic farms, biennial bearing occurred in every orchard with apples and sour cherries. In some cases, the yields were only $20 \%$ of that from the previous year. The direct costs of apple production were lower in organic farms and accounted for 10259 PLN per hectare, while in conventional ones, costs were 10531 PLN per hectare. The mechanical and manual weed control accounted for $31.1 \%$ of the total direct costs of production. Pest and disease control accounted for $31.3 \%$ of the total direct costs of production (Fig. 1). In the conventional system, $43.4 \%$ of the total direct costs were for pest and disease control, $27.7 \%$ for harvesting of the fruit, and only $8.9 \%$ for weed control.

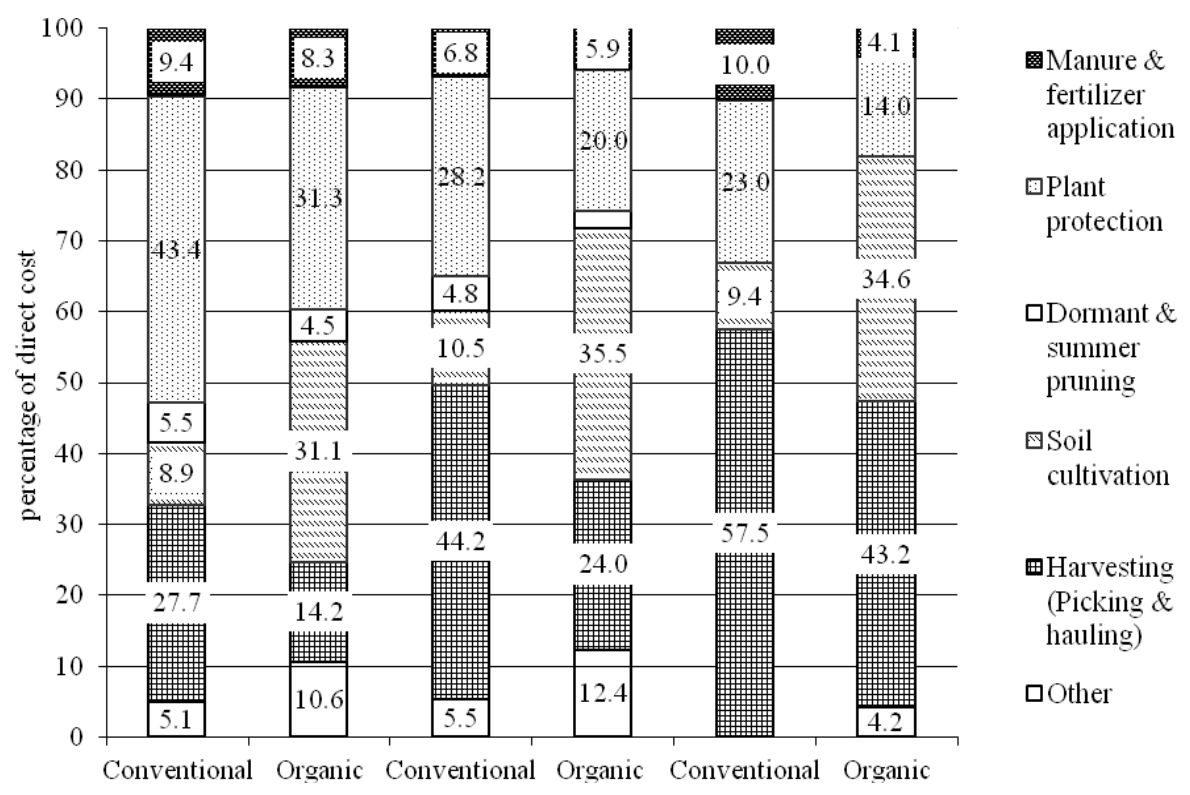

Apples

Sour cherries

.Strawberries

Figure 1. Structure of the direct cost of organic and conventional cultivation 
In organic strawberry production, average yields amounted to 8.0 tons per hectare while in conventional production, 9.2 tons. The direct costs of strawberry production were higher for organic farms - 14280 PLN per hectare, due to higher expenses for manual work (weeding). Strawberry production cost for conventional farms was 12730 PLN. The highest cost in both organic and conventional production was the harvesting; it accounted for $43.2 \%$ of the total direct cost in organic production and $57.5 \%$ in the conventional one (Fig. 1).

The sour cherry yields were low in both the conventional and organic systems. The average yields for the organic farms amounted to 4.1 tons per hectare while for the conventional ones, 6.5 tons. The direct costs of sour cherry production were higher for the organic farms - 9445 PLN per hectare, while for conventional ones - 8544 PLN. The weed control accounted for $35.5 \%$ of the total direct costs of pro- duction. Harvesting came next, which constituted $24.0 \%$ of the total direct costs of production. In the conventional system, the opposite was true; $10.5 \%$ was for weed control, while $44.2 \%$ for fruit harvesting.

Organic fruit production methods are more time-consuming and labour intensive. The number of machinery hours spent on one hectare was $48.8 \%$ higher in organic apple production than in conventional production. The number of man hours per one ha was $12.5 \%$ higher, but the yields were lower in the organic system (Fig. 2, 3). In organic strawberry production, the number of machinery hours spent on one hectare was $18.2 \%$ higher than in the conventional one, and also the number of man hours per one ha was $25.7 \%$ higher mostly due to the weeding problem. In organic sour cherry production the labour inputs were respectively, $126.9 \%$ and $4.0 \%$ higher than in conventional one.

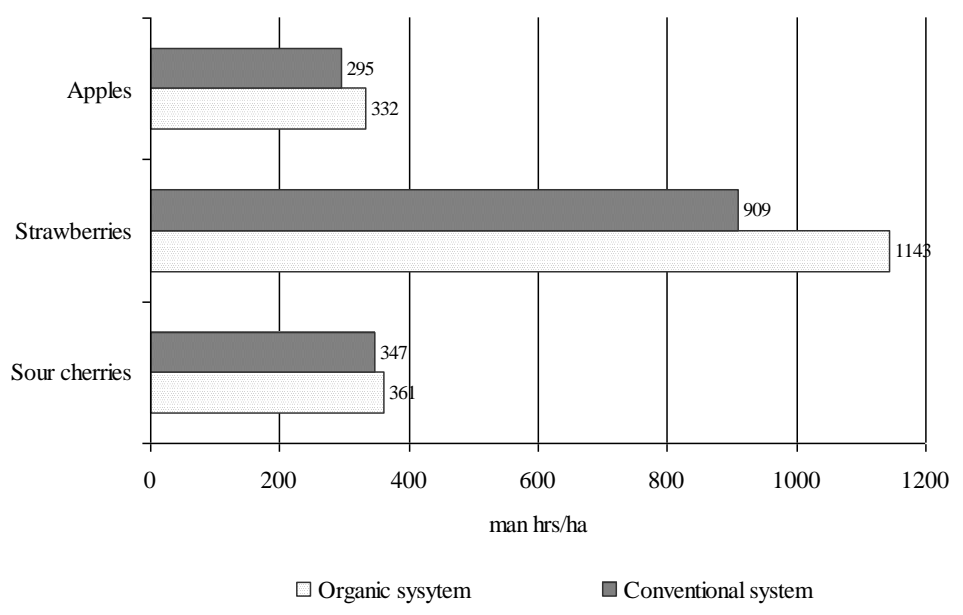

Figure 2. Inputs of human labor for organic and conventional cultivation 
Economics of the 2009-2012 organic apple...

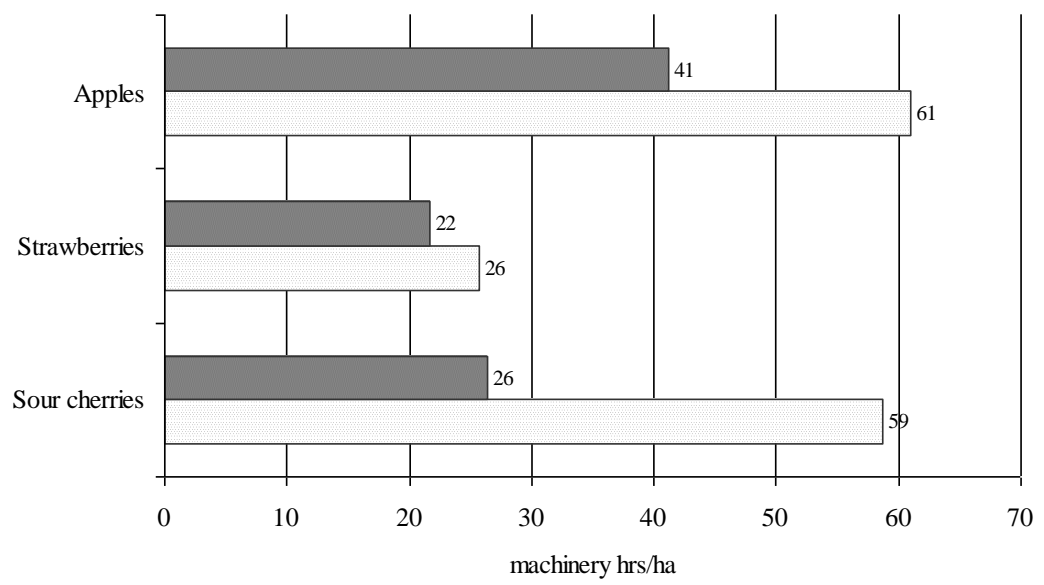

$\square$ Organic sysytem

$\square$ Conventional system

Figure 3. Inputs of bullock labor for organic and conventional cultivation

Table 1. Costs and other economical features for apples, strawberries and sour cherries cultivated in two systems: organic and conventional

\begin{tabular}{|c|c|c|c|c|c|c|}
\hline Items & $\begin{array}{c}\text { Apples } \\
\text { conventional }\end{array}$ & $\begin{array}{l}\text { Apples } \\
\text { organic }\end{array}$ & $\begin{array}{l}\text { Strawberries } \\
\text { conventional }\end{array}$ & $\begin{array}{c}\text { Strawberries } \\
\text { organic }\end{array}$ & $\begin{array}{l}\text { Sour cherries } \\
\text { conventional }\end{array}$ & $\begin{array}{l}\text { Sour } \\
\text { cherries } \\
\text { organic }\end{array}$ \\
\hline $\begin{array}{l}\text { Yields } \\
\left(\mathrm{dt} \mathrm{ha}^{-1}\right)\end{array}$ & 257 & 130 & 923 & 801 & 648 & 415 \\
\hline $\begin{array}{l}\text { Average price } \\
\left(\mathrm{PLN} \mathrm{kg}^{-1}\right)\end{array}$ & 1.18 & 1.66 & 3.33 & 4.19 & 2.19 & 2.78 \\
\hline $\begin{array}{l}\text { Gross income } \\
\left(\mathrm{PLN} \mathrm{ha}^{-1}\right)\end{array}$ & 30227 & 21515 & 306733 & 33552 & 14196 & 11516 \\
\hline $\begin{array}{l}\text { Direct cultivation cost } \\
\left(\mathrm{PLN} \mathrm{ha}^{-1}\right)\end{array}$ & 10531 & 10259 & 12730 & 14280 & 8544 & 9445 \\
\hline $\begin{array}{l}\text { Recapture of establish- } \\
\text { ment cost } \\
\left(\mathrm{PLN} \mathrm{ha}^{-1}\right)\end{array}$ & 3835 & 2850 & 5130 & 5050 & 3880 & 2750 \\
\hline $\begin{array}{l}\text { Grading costs } \\
\left(\text { PLN ha }^{-1}\right)\end{array}$ & 3087 & 2340 & 0 & 0 & 0 & 0 \\
\hline $\begin{array}{l}\text { Storage cost } \\
\left(\mathrm{PLN} \mathrm{ha}^{-1}\right)\end{array}$ & 6045 & 3315 & 0 & 0 & 0 & 0 \\
\hline $\begin{array}{l}\text { Overhead } \\
\left(\text { PLN ha }^{-1}\right) \\
\end{array}$ & 1580 & 1539 & 3183 & 3570 & 1282 & 1417 \\
\hline $\begin{array}{l}\text { All costs (Total) } \\
\left.(\mathrm{PLN} \mathrm{ha})^{-1}\right)\end{array}$ & 25078 & 20303 & 21043 & 22899 & 13705 & 13612 \\
\hline $\begin{array}{l}\text { Net income } \\
\left(\mathrm{PLN} \mathrm{ha}^{-1}\right)\end{array}$ & 5149 & 1212 & 9630 & 10653 & 491 & -2096 \\
\hline $\begin{array}{l}\text { Support payments } \\
\left.(\mathrm{PLN} \mathrm{ha})^{-1}\right)\end{array}$ & 0 & 1670 & 0 & 1670 & 0 & 1670 \\
\hline $\begin{array}{l}\text { Final economical result } \\
\left(\mathrm{PLN} \mathrm{ha}{ }^{-1}\right)\end{array}$ & 5149 & 2882 & 9630 & 12323 & 491 & -426 \\
\hline
\end{tabular}


The organic production of apples was less profitable than conventional production (Table 1). Besides lower yields, such a result is a reflection of the achieved unit price - 1.66 PLN per kg, which was not high enough to compensate for the lower yields. In the case of strawberries, the opposite was true - the organic production gave more net income than the conventional one. The great amount of labour required for weed control acts as a barrier for the further expansion of organically cultivated strawberries. Some technological improvements are needed to improve the situation. The 2009-2012, sour cherry production on the investigated farms brought losses to those farmers using the organic system. In the conventional mode, the financial outlook was barely positive because of the low prices in 2009 and difficult weather conditions in 2010 and 2011.

\section{DISCUSSION}

The results confirm the research published by the vast majority of authors, reporting the lower level of yields in organic fruit production compared with conventional production. The organic yields presented in this paper are in the lower range. In the case of apples, the yields are similar to those shown in research and calculations based on extensively managed orchards, like those with yields of $10 \mathrm{t} / \mathrm{ha}$ in UK (Firth, 2005) and of 10-17 t/ha in Norway (Ascard et al., 2010). According to other studies, organic apple yields were found to be $50-80 \%$ of those in conventionally managed orchards
(Weibel et al., 2004; Gianessi and Williams, 2011). The lower and inconsistent yields of the organic apple orchards are the result of unsatisfactory crop load management, higher pest and weed pressures, and nutrient deficiencies (Peck et al., 2006; Jönsson, 2007). Also the biennial bearing pattern exhibited in the organic system in this research and other studies (Peck et al., 2006), had a negative impact on financial returns. In the case of the strawberry yields in this study were on a similar level in organic and the conventional system, but both modes were extensively managed (without irrigation system). In the USA, organic strawberry yields were found to be $50-60 \%$ of the overall average (http://www.scribd.com/doc/47829728/ A-Detailed-Analysis-of-US-OrganicCrops), and yields of tart cherries were about $25 \%$ of the overall average, which corresponds to the results of this study

The organic fruit production costs in Poland are relatively low, mainly due to lower labour costs. For example, the costs of organic apple production and harvest were 0.38 euro per $1 \mathrm{~kg}$ in Poland (at an exchange rate of 4.11 PLN/euro). In Sweden, for orchards of comparable size, they were 1.14 euro per $1 \mathrm{~kg}$ (Ascard et al., 2010). Labour cost per 1 man $\mathrm{h}$ ranged from 2 to 3 euro in Poland while in Sweden they were 17-22 euro (Ascard et al., 2010). In this study, the cost on the per $\mathrm{kg}$ basis for organic apples was about $60 \%$ higher than for the apples grown in the conventional system, which corresponds to the result achieved in Sweden. 
Human labour inputs are higher in organic production than in conventional production, in the case of apples they were $12.5 \%$ higher which constituted about 40 hours. In Switzerland human labour inputs were, on average, $7 \%$ higher for the organic system, but the need for additional hours on a hectare basis could be as high as 40 hours for weed control, about 100 for manual thinning, and 30 for rodent control (Weibel et al., 2004). The number of machinery hours spent on one hectare was $48.8 \%$ higher in organic apple production than in conventional production. Accordingly to research done at BASF Company, organic apple production has a $70 \%$ higher use of machinery compared to conventional production.

In Poland, 1 ha of an organic apple orchard brought only about 700 euros, including 385 euros in support payment. In Sweden, the production outcome was zero, even though the support payment was higher - 970 euro (Ascard et al., 2010). In Switzerland, the financial benefits of organic orchards were $16 \%$ higher compared to integrated fruit production (Weibel et al., 2004). In Poland it was the opposite: the conventional production brought about a $75 \%$ higher income than the organic one. The general results of this work are in agreement and confirm the conclusions drawn in previous research of authors on the subject (Brzozowski and Zmarlicki, 2010).

\section{CONCLUSIONS}

- Organic apple and sour cherry producers in Poland are hampered by low and variable yields also their ability to control pests and diseases is limited in comparison with the conventional sector.

- New plantings of orchards with varieties suitable for the organic mode could help to increase the profitability of organic production.

- The limiting factor for the further expansion of organic strawberry production is the high demand for manual labour needed for weed control, hence important technological improvements are needed.

- Strong support on an on-going basis from science and extension agencies in Poland is necessary to increase the quantity and quality of yields in organic production. Special marketing activities are also vital for increasing the profitability of the production.

\section{RERERENCES}

Ascard J., Håkansson B., Hansson A., Stridh H., Söderlind M. 2010. Cost price calculation for organically and conventionally grown apples in Sweden, SLU Alnarp, 2010 Online at: http://www.ecofruit.net/2010/46_RP_J _Ascard_B_Hakansson_A_Hansson_et_al_S304bis312.pdf.

Brzozowski P., Zmarlicki K. 2010. Economics of organic apple and strawberry production in Poland in the years 20072009. J. FRUIT ORNAM. PLANT RES. 18(2): 255-264.

Firth Ch. 2005. Economics of organic top fruit production (OF0305). The Initiative on Organic Research (IOR), Henry Doubleday Research Association (HDRA). Online

at: 
http://www2.defra.gov.uk/research/project _data/More.asp?I=OF0305\&SCOPE $=0 \&$ $\overline{\mathrm{M}}=\mathrm{PSA} \& \mathrm{~V}=\mathrm{EP} \% 3 \mathrm{~A} 200$.

Gianessi L., Williams A. 2011. European organic apple production demonstrates the value of pesticides. International pesticide Benefits Case Study No.44. CropLife Fundation. Crop Protection Research Institute.

Jönsson Å.H. 2007. Organic apple production in Sweden: cultivation and cultivars. Swedish University of Agricultural Sciences, Balsgård, Thesis (Ph.D.), 33p.

Peck G.M., Andrews P.K., Reganold J.P., Fellman J.K. 2006. Apple orchard productivity and fruit quality under or- ganic, conventional, and integrated management. HORTSCIENCE 41: 99107.

Weibel F.P., Häseli A., Schmid O., Willer H. 2004. Present status of organic fruit growing in Europe, ISHS: XXVI International Horticultural Congress: Sustainability of Horticultural Systems in the 21st Century, ACTA HORTIC. 638: 375-385.

http://www.agro.basf.com/agr/AP-Internet/en/content/sustainability/eco-efficiencyanalysis/case-study-organic-applescompared-to-conventional http://www.scribd.com/doc/47829728/A-

Detailed-Analysis-of-US-Organic-Crops

\title{
EKONOMIKA EKOLOGICZNEJ PRODUKCJI JABŁEK, WIŚNI I TRUSKAWEK W POLSCE W LATACH 2009-2012
}

\section{Piotr Brzozowski i Krzysztof Zmarlicki}

\author{
S T R E S Z C Z E N I E
}

W Polsce w latach 2003-2010 powierzchnia certyfikowanych upraw ekologicznych wzrosła 8,5-krotnie, osiągając wielkość 518 tys. ha, co stanowiło 2,8\% gruntów ornych w kraju. W pracy przedstawiono koszty i opłacalność produkcji w ekologicznych gospodarstwach z produkcją jabłek, wiśni i truskawek. Rezultaty badań tych gatunków porównano do odpowiednich gospodarstw z produkcją konwencjonalną w Polsce. Badania prowadzono w trzydziestu dwu gospodarstwach sadowniczych, dwunastu z produkcją ekologiczną i dwudziestu z konwencjonalną. Jednym z najważniejszych problemów w produkcji ekologicznej, znajdujących swe odzwierciedlenie w kosztach, stanowiła walka $\mathrm{z}$ chwastami i utrzymanie gleby w sadzie. Konwencjonalna produkcja jabłek w badanych gospodarstwach okazała się nieco bardziej opłacalna niż produkcja ekologiczna. Nieopłacalna okazała się ekologiczna produkcja wiśni. Ekologiczna produkcja truskawek była w badanych latach bardziej opłacalna niż produkcja konwencjonalna.

Słowa kluczowe: jabłka z produkcji ekologicznej, wiśnie z produkcji ekologicznej, truskawki z produkcji ekologicznej, opłacalność, koszty 